\title{
Care for the Earth as Archetypal Emergence in the Christian Tradition
}

Jonathan Erickson, M.A.*

Pacifica Graduate Institute

This paper explores the renewed emphasis of care for the Earth in the Christian tradition as an emerging archetypal shift toward Earth-centered psyche. Jung proposed that the Christian psyche would continue to evolve toward greater psychic wholeness. The current trends toward environmental awareness in religious communities offer compelling parallels to Jung's ideas about the evolution of religious consciousness.

"If faith (God) is said to be able to move mountains (Job 9.5; 1 Cor. 13.2), scholars need to explore how belief systems could 'move' climates" (Gerten \& Bergmann, 2012, p. 13).

We live in an age when an extraordinary consensus exists among scientists that human-caused climate change threatens catastrophic consequences for the planet (Cook et al., 2016) and when our best and brightest minds toil to find solutions to the crisis at hand (Foquet, 2013); yet at the same time we watch day by day as the new US administration moves to roll back environmental protections. For those who follow and believe in the basic values and principles of science, this is a terrifying moment. It is natural for progressive thinkers to point fingers and for depth psychologists to go in search of root psychological causes. Christianity, with its historic associations to patriarchal rule, has often been a fast and easy target (Foltz, 2014). But while there are clearly aspects of Christianity that have contributed to the crisis, it would be a logical error and a strategic tragedy to mistake the part for the whole. A deep look into the Christian psyche reveals a complex picture, and I will argue that the potential for a great alliance between science, environmentalism, and religion is strong. Indeed, a palpable movement toward science and religion working together to solve environmental problems dates back at least to the Religion and Ecology conferences at Harvard from

*Author contact: jonathan.bodywork@gmail.com 
1996-1998 (http://www.fore.yale.edu). And, as the following discourse will demonstrate, the roots of this movement go far deeper.

Nevertheless, criticism of Christianity's role in the environmental crisis has been strong. In 1967 historian Lynn White published an influential article in the journal Science entitled "The Historical Roots of the Ecological Crisis," in which he essentially blamed Christianity outright for the unfolding ecological crisis (White, 1967). White specifically emphasized the Christian doctrines of dualism and human dominion over a fallen world as primary culprits in the looming environmental disaster. Yet 50 years later a remarkably different situation unfolds: in 2015 Pope Francis issued a new statement of doctrine: On Care for our Common Home. This statement declared a "crisis" of anthropocentrism, a crisis that has compromised "the intrinsic dignity of the world" (p. 34). Francis called on Christians to take immediate action to address the ecological crisis before it is too late. How might we account for such a stunning transformation? In this paper I attempt to answer that question using the framework of Jung's writings on Christianity and his belief that the Christian church can and must evolve. Reviewing recent sociological evidence, I argue that such renewed emphasis on care for the Earth within the Christian tradition indicates an emerging archetypal shift toward a more Earthcentered Christian psyche.

This is a topic close to my heart for several reasons. The environmental crisis we now face on the planet is already devastating, with mass extinctions already underway and global warming threatening the lives of millions in the decades to come. At the same time, I have noticed over the years a consistent hostility towards the Christian church with regard to this issue, no doubt in part because our media are more prone to cover conservative fundamentalists denying climate change than progressive churches fighting to stem the tide. At the same time, I have witnessed the incredible passion that green Christians bring to their environmental advocacy. In a time of crisis, we cannot afford to make enemies of our potential allies, and I believe that the Christian church, as a whole, will prove a vital and perhaps indispensable ally in healing our planet and securing a future for the generations to come.

I must confess a certain amount of personal transference to the topic as well. Like Jung, I am the son of a Christian minister; also like Jung, I was raised by a mother who has strong pagan inclinations and a great love for the natural world. She taught me that nature and all the forms of life within it are sacred. Between them, I have come to recognize the complexity and beauty of religious belief, while remaining ever-mindful of its shadow. In this sense the need to forge harmony and balance between Christianity and ecology is very much in my DNA. 


\section{Jung on Christianity}

Jung had something of a lifelong preoccupation with religion in general and Christianity in particular. Jung's autobiography Memories, Dreams, Reflections (1961/1989) details both the complexities of his relationship with his father, a clergyman, and a number of formative experiences around Christian symbolism and doctrine. Professionally, he would come to write extensively about Christianity, beginning with "A Psychological Approach to the Dogma of the Trinity" (1942/1958), which in many ways presented the basic outline of ideas that he would develop in later works. A common point of confusion in understanding Jung's religious writings is the failure to recognize that Jung predominantly addressed the issue psychologically rather than theologically. Leaving speculations about ultimate metaphysical realities to others, Jung was primarily concerned with how God and religious mythology functioned as meaningful psychological imagery in the individual and the culture. Certainly this imagery could point towards a genuine divinity, but it could also be incomplete, in need of further evolution. As Jungian analyst Murray Stein explained it: "none of these [images], however, are full expressions of the Ground of Being, of Divinity itself. They are humanly generated images based upon emotionally convincing numinous experiences, and the mythopoetic and theological imagination" (Stein, 2014, p. 18). Thus, Jung's primary interest was in the psychological aspect of religious experience, and he explicitly left the theological dimension of religion to others. In this way, Jung was able to respect religion as a psychological container for the divine, while still holding space to analyze and criticize the structure of the container itself.

Stein argued in Jung's Treatment of Christianity (1985) that in Jung's later years, he attempted to offer therapeutic treatment to Christianity through his writings, a therapy of ideas. Stein further argued that Jung was both trying to address the illness of his "spiritually defeated father," as well as a more objective concern for the larger culture's tension between tradition and modernity (p. 108). Jung believed that the Western psyche had deep roots in the Christian tradition, that is, that Christianity partially structured the way Westerners experience the world, both consciously and unconsciously. Equally important, Jung feared that the West, by losing touch with the deeper symbolic meanings of its own tradition, had experienced a "loss of soul" throughout modernity. Since a psychological analysis of religion was vital to the formation of a healthier society, Jung began to speak of Christianity as something that needed to evolve, heal, change, and become more whole.

In Jung's (1942/1958) analysis of the archetypal meanings underlying the Christian Trinity, he began with a discussion of the archetype of number in the ancient Greek 
philosophies of Plato and Pythagoras. Here the number one expressed undifferentiated potential, while the number two introduces an "other," creating duality, difference, and polarity. To reconcile the polarity, to find harmony between the opposites of one and other, a third mediating principle emerges. Thus, the number three represents reconciliation and balance between a polarized pair. In the Trinity, the seemingly irreconcilable opposites of a transcendental father-god and a fleshly (or earthly) son-God find their unity in the mystery of the Holy Spirit, the third figure in the Trinity. This basic structure mirrors Jung's psychological notion of the transcendent function, whereby polarized conscious and unconscious positions in the psyche are resolved in the emergence of an integral third, usually in the form of a symbol. In this sense, the Trinity represents a wholly positive and progressive process of psychological growth.

But Jung felt that something vital was still missing here. In his understanding of archetype and number, true psychological wholeness was to be found in the balanced opposites of a quaternity; the Trinity was leaving something out. This is not necessarily as esoteric as it sounds: it is the nature of the number three that any three points plotted in space will always make a flat plane. It is geometrically impossible to derive depth in the dimension of space without plotting a fourth point. For Jung, such flatness implied abstraction, ungroundedness, and a loss of embodied reality in favor of a transcendental realm of ideas. This is not to say that the Trinity is somehow bad or false, only that archetypally it naturally seeks a greater depth of balance. Adding the fourth point to create a quaternity allowed the flat abstraction to come into space, into the physical world, and in so doing become embodied and more fully real. Jung's favorite symbol to express this was the mandala, the squaring of the circle that reconciles the opposites within into wholeness. Psychologically speaking, such a union of opposites was the realization and integration of the deep self with all its complexities and contradictions.

Thus, just as Jung advocated for his patients' journeys toward greater psychic wholeness by integrating the disowned aspects of their psyche into consciousness, he also felt that Christianity had some important integrating work to do. The archetypal basis of Jung's treatment of Christianity was that it is out of balance, an abstract trinity, missing the fourth element of the mandala. As with a human patient, the fourth, disowned element was not only missing but actually split off and repressed. The question then becomes: what has the Christian church been repressing throughout its long history? For Jung, these disowned aspects of reality include the body, the instincts, sexuality, the feminine, and, most germane to the present topic, the natural earthly realm. For the church to evolve towards wholeness, its god-image would have to expand to integrate these rejected elements. 
Psychologically Jung (1951/1969) understood Christ as an image of the archetypal Self - the inner unity of the developed man. But this God-image was ultimately incomplete because it rejected a part of its own nature: its own dark side. The dark side was split off and demonized as the personification of evil itself in the image of Satan, a darkness that must be destroyed rather than integrated. In Jung's analysis, this archetypal structure encourages repression in the individual and a stance of dominion in the collective: the tyranny of the ego over self and over world. But Jung does not end on this criticism. Rather, he frames it as a story of psychological and religious evolution that has yet to be completed. As human consciousness expands and evolves, so does the Godimage: for Christianity to come to full fruition in an awakened humanity, the fourth aspect must emerge to complete the quaternity. Jung believed that he had already seen signs of such a transformation in his own lifetime.

Does this model for transformation align with what we are seeing today? Could the Christian church be turning to acknowledge those split-off aspects, embracing a more complex God-image that has a feminine nature to balance the masculine, and a presence in and of the natural embodied world, rather than always remaining apart from it? I contend there is strong reason to think so. But to understand the transformation fully, we must go back to the beginning.

\section{Christian Quaternity: A Brief History}

Christianity has taken many twists and turns throughout its very long history, and critics may be surprised to learn just how varied the Christian experience has been over the centuries. In the Passion of the Western Mind, Tarnas (1991) outlined two contrary streams of thought from the earliest moments of Christianity. In what Tarnas called the dualistic stream, nature itself was fallen, and the earth awaited redemption from a transcendent God apart from and above it all. The dualistic stream would become the taproot of the anti-environmental church, the version of Christianity that sees the Earth as a subject for human dominion at best, and a cursed, evil place at worst. In this worldview, humanity was fundamentally alienated from God, and Earth was the location of that alienation.

But Tarnas also referred to an alternative worldview within early Christianity, what he called the exultant stream. For exultant early Christians, the divine had already miraculously entered the natural world through the birth of Christ into worldly time. Christ's incarnation in the earthly realm was a blessing upon the world, a redemption of nature and everything in it. If God above was not in the world exactly, God was still connected to the world, penetrating it as force that loved and blessed the creation. The exultant stream was more prone to celebrating the presence of the divine in lived 
experience, and it focused on a message of love and inclusive redemption. Thus, even in those historical epochs when the dualistic stream of Christianity was most dominant, the church also harbored the seeds of an opposing worldview in its teachings.

Furthermore, to speak comprehensively of Christianity, we must remember that in addition to the Western tradition with which Americans are most familiar, there exists also an Eastern tradition. The Eastern Orthodox Church followed its own line of development and eventually broke with the Catholic Church in $1054 \mathrm{CE}$. Though this tradition arguably had minimal impact on either Jung or the evolution of Christianity in the West, it nonetheless offers an important window into the broader potentialities of the Christian worldview. Apropos to the topic at hand, the Eastern Orthodox church has long viewed the physical world as a gift from a loving God, something that can be distorted by $\sin$ but is inherently good (Fitzgerald, 2005). Eastern worship services have long affirmed the goodness and divinity of the physical world by incorporating earthly objects such as fruit, flowers, and oil into their worship. Foltz (2014) explicitly criticizes White's 1967 paper for omitting the hagiography of Eastern saints communing with animals: "St. Gerasimos with his helpful lion, St. Seraphim with his cooperative bear, and Elder Paisios with his guileless snakes effortlessly join company with St. Francis and his penitent wolf' (p. 188). There is historical emphasis in Eastern Orthodox theology that all creatures are worthy of divine salvation, not only humans (Northcott, 2009). The physical world has been spiritually polluted by human pride, but the creation itself will one day be redeemed.

That said, the dualistic stream was often dominant in the West, as exemplified in the venerated figure of Augustine of Hippo (350-430 CE), who wrote that succumbing to "the flesh" was at the heart of man's fall (Tarnas, 1991, p.144). According to Augustine, man, as an embodied carnal being, was inherently sinful. Concupiscence, or fleshlyappetite, was an expression of humanity's fallen nature, and the road to redemption was to rise above this world of sensuality and embodiment. The only true freedom for man was in accepting the redeeming grace of a transcendental God, as administered by an authoritarian church. Ironically, Augustine's early spiritual affiliation with the fleshhating Manichean gnostic sect (Smith, 2005) may have profoundly influenced the church for generations to come. Augustine's dualism is certainly more in keeping with some of the modern stereotypes of Christianity as being sex-negative and hostile toward the natural world. Tarnas (1991) encouraged us to consider that Augustine lived and formulated his thoughts as the Roman Empire was crumbling. The human world seemed to be in a slow and inevitable decline, and seeing no hope for progress on the earthly plane, Augustine awaited the Kingdom of God instead. 
But dominant or not, the dualistic stream of Christianity is not the whole story of the Western church, and the Christian tradition as a whole contains many prominent figures who advocated for a different relationship between humanity and the Earth. Among the earliest is Hildegarde of Bingen (1098-1179 CE) - a Benedictine abbess, writer, composer, naturalist, and mystic visionary. Schipperges (1997) wrote that Hildegarde was regarded as a prophet by many, even in her own time. She claimed to have visions that involved all five senses, and she emphasized the body and nature repeatedly in her holistic writings. She taught that all creatures have divine radiance and that the creation is infused with healing life force: "There is a power in eternity," Hildegarde wrote, "and it is green" (qtd. in Schipperges, 1997, p. 67). Hildegarde's writings emphasized the importance of harmony in nature and spoke of a reciprocal relationship between humans and the natural world. She even believed that humans could disrupt the natural harmony and bring suffering to the land: "all the elements and all the creatures cry out at the blaspheming of nature" (qtd. in Schipperges, 1997, p. 57). This clear concern for humanity's negative impact on the environment shows her to be a woman a thousand years ahead of her time.

A century later in Italy we find perhaps the most famous early Christian figure to advocate for the natural world: Francis of Assisi (1182-1226). His myth and folklore paint a portrait of a man who truly loved nature and the creatures within it. The mythology surrounding Francis includes tales of his ability to communicate directly with animals. The beasts of the wild were said to be naturally drawn to his peaceful nature. Indeed, Francis is rarely depicted without a peaceful animal presence contained in the image. Tarnas (1991) described Francis as having "a mystical joy in the sacred fellowship of nature" (p. 179). In White's famous 1967 paper criticizing Christianity, he explicitly names Francis of Assisi as a contrary case, describing the saint's advocacy for nature in some detail. White ends the paper with the suggestion that Francis should be named the patron saint of ecology. Two decades later, Pope John Paul II would officially do just that, naming Saint Francis the Patron of Ecology in 1979.

In fact, the current Pontiff, Pope Francis, took his name in honor of Francis of Assisi's work. In the 2015 Encyclical letter (On Care for our Common Home), Pope Francis declared that Francis of Assisi's harmony with all living creatures was a historic act of healing the split between humanity and God after the expulsion from Eden. This teaching reframes Saint Francis from an outlier to a key healer of the human-God relationship and places care for the natural world at the heart of that healing. In our current Pope's reading, Saint Francis' essential lesson to humanity is that loving and honoring nature brings us closer to God. 
A final Western historical figure to consider is Thomas Aquinas (1225-1274). In the 13th century, Aquinas asserted that because nature was a work of divine creation, the study of nature could be a source of further learning about the wisdom of God (Tarnas, 1991). Tarnas wrote of Aquinas' theology: "nature's order enhanced human understanding of God's creativity. .. . Nature and spirit were intimately bound up with each other, and the history of one touched the history of the other" (p. 179). The case of Aquinas reminds us that historically Christian theology was deeply influenced by Greek philosophy, including the Neoplatonic idea of the World Soul. In this ancient formulation, nature herself was an animate emanation of the divine mind. Church leaders wrestled to unite Greek philosophy with scripture in various ways throughout the ages, and in Aquinas the World Soul archetype found perhaps its most enduring integration, prior to modernity.

\section{Modern Christianity and Care for the Earth}

In keeping with Jung's proposal (1942) that the split between Christianity and nature was inherently connected to the rejection of the feminine, it follows that the integration of the feminine in the church would herald an awakening consciousness of the Earth. Jung was profoundly impressed and heartened by the Assumptio Mariae in 1950, when Pope Pius XII declared as official doctrine that the Virgin Mary had bodily ascended to Heaven. For Jung, this symbolized the embodied feminine joining the Godhead, paving the way for a quaternity in Christian consciousness. This event was followed, just three decades later, by the aforementioned declaration that Francis of Assisi would henceforth be recognized as the Patron Saint of Ecology.

From these beginnings, the Catholic Church has moved increasingly toward advocating greater care for the Earth, and in 2007 the Vatican announced that it would become the world's first fully carbon-neutral state. Agliardo (2013) has researched the ways the US Catholic Church has responded to climate change, and he details two main avenues of approach. The first is the environmental justice perspective: that global warming and environmental degradation will ultimately have the greatest negative impact on the most vulnerable populations of humans worldwide and that advocating for the Earth is at heart a vital humanitarian issue. Just as the church has long carried an ethical injunction to help the needy and the poor, it also views environmental protection as an ethical imperative to care for the defenseless.

Perhaps even more germane to the present discussion is Agliardo's second Catholic approach to climate change, which as a movement has come to be called "creation spirituality." This approach revives the ancient notion that God's grace abides in the creation, and it adds an ethical mandate to protect and care for the creation itself as a 
sacred expression of the divine. Creation spirituality generally rejects anthropocentrism and calls for a new harmony between humanity and the natural world, based on the premise that the Earth is sacred and should be treated with the utmost care and respect. The most famous figure in creation spirituality is perhaps the Catholic priest Father Thomas Berry. Berry (1998) wrote:

Most of all we need to alter our commitment from an industrial wonderworld achieved by plundering processes to an integral earth community based on a mutually enhancing human-Earth relationship. The move from an anthropocentric sense of reality to a biocentric norm is essential. (p. 30)

Clearly this movement has gone well beyond notions of dominion over nature to emphasize harmonious relationship itself, shifting consciousness from an anthropic center to a natural one. That said, although creation spirituality has grown tremendously within the Catholic Church in recent decades, it is by no means ubiquitous and has in some cases met with great resistance. Prominent creation spiritualist Matthew Fox left the Catholic Church altogether for fear of censure and joined the Episcopalians instead (Agliardo, 2013). While a new consciousness has taken root in the church, there are still ample forces of resistance.

This internal rift makes it all the more astounding that in 2015, the mantle of care for creation would be taken up so unequivocally by the Pope himself. The 2015 Encyclical Letter On Care for our Common Home specifically refers to anthropocentrism as a "crisis" and to environmental degradation and global warming as ethical imperatives of the highest order. Pope Francis argues for the honoring of every creature in the creation and rejects the notion that the mention of "dominion" in Genesis gives humans the right to exploit and destroy natural resources. He calls for a new relationship to the Earth, a new valuation of progress, and a new, ecologically harmonious lifestyle. While not all Catholics may agree with the Pope, it is nevertheless a profound shift to see such ideas coming from the top, instead of only ever crying out from the shadows below.

As might be expected from a collection of groups that claim no internal unity, the situation among Protestants is somewhat more complicated. Even so, the overall movement of the church seems surprisingly clear. According to Roberts (2012),

If we consider the mainstream Protestant, Catholic, and Orthodox churches and statements from ecumenical bodies, it is easy to conclude that Christians - at least officially-are convinced both of anthropogenic climate change and the need for concerted action to mitigate the effects. (p. 107) 
In defiance of the stereotype, Christianity on the whole appears to be increasingly onboard to mitigate the human causes of climate change. The problem of antienvironmental Christianity is rather to be found in the deeply divided Evangelical population, which represents more than a quarter of American Christians. Roberts recognized Evangelicals as an especially important group because they number close to half a billion worldwide, are growing, and tend to be politically engaged. Therefore, the worldviews of Evangelical Christians are likely to have a substantial impact on how humanity responds to our current environmental crisis.

McKeown (2006) was the first to characterize the contentious split within Evangelical Christianity as a divide between the "greens" and the "browns"- a usage that has since gained traction. In the emergent paradigm of green evangelism, Earth is the creation of God, and humans must respect and honor God by caring for creation. As McKeown noted, this is not mere theology: The Evangelical Environmental Network (EEN) was founded in 1992 and "The Evangelical Declaration on the Care of Creation" was signed by 200 Evangelical leaders in 1994 and disseminated around the world. In 2006, the "Evangelical Climate Initiative" was widely reported on, including coverage in the science journals Nature and Science. This initiative is a campaign of US church leaders and organizations to combat global warming actively.

By contrast, the "brown Evangelicals" cleave to the old dualistic doctrine that nature has been cursed since the Fall and that man has been granted full dominion over the Earth to do with as he pleases. A constituency of such believers posted the Cornwall Declaration to some 35,000 churches in 2000, outlining their beliefs that while stewardship of the creation was important, free markets were even more important, since the Earth has essentially been given to humanity as a resource to be used. This formulation of stewardship was largely the creation of movement leader Calvin Beisner, for whom care for the Earth was primarily a matter of subduing and taking advantage of the natural resources given to aid in man's productivity. Shortly thereafter the Cornwall Alliance was formed to outline a direct rejection of the idea of human-created global warming.

It seems, then, that the polarization within Christianity about care for the earth falls at least partly along deeper political and ideological lines. Zaleha and Szasz (2014) discussed the strong associations among brown evangelicals, conservative free-market ideology, and the Republican party. The authors also pointed out that Beisner's message was spread largely through funding by the Koch brothers, ExxonMobil, and other big extraction industries. Furthermore, a cultural openness to apocalyptic eschatology may serve as a deterrent to long-term considerations. As with Augustine at the fall of the Roman Empire, apocalyptic thinking places emphasis not on the world we live in, but 
on the promised world to come. Even worse, a belief that our world will soon end makes preservation of that world a fool's errand.

The brown Evangelical movement has furthermore become a resource for conservative Christians from other denominations, unifying diverse groups with ideology where they might disagree theologically. Zaleha and Szasz (2014) note the particularly strong ties between the brown Evangelicals and the brown Baptists. The rift eventually became an explicitly political struggle as conservatives began tarring green Christians as socialists who present a fundamental threat to American freedom.

But it is an oversimplification to assume that political ideology is the only factor at work. Christianity is diverse, and there are certainly conservative congregations that nevertheless recognize the value in caring for the Earth. Townsend (2014), for example, showed that the American Presbyterian church has been remarkably consistent in its proenvironmental stance on climate change, despite being a majority Republican denomination. Likewise, the Eastern Orthodox Church, while host to its own conservative tendencies, has nevertheless emerged as a leader on environmental causes, advocating the vital need to care for creation, to heal humanity's sins against the Earth and to recognize the physical world as the dwelling place of the divine (Northcott, 2009).

There is a natural impulse to point the finger at the culprits of this crisis, to identify and attack a nefarious "other" on whom the situation can be blamed. But I contend that if we truly seek a solution to our environmental challenges, we must be discerning and precise in our criticisms. The church, like all institutions, harbors elements both progressive and regressive. And even in casting blame more precisely (at the brown Evangelicals, for example) I question if it is helpful to attack their religion and spirituality per se, rather than exposing the political ideologies that have become entangled with their religiosity. If there is a solution to this great divide, I propose that it lies not in attacking the deepest spiritual beliefs and experiences of others but in digging down to the deeper values that we all still share. From its earliest beginnings and throughout the long sweep of history, Christianity has contained the seeds of a fierce care for creation. Rather than make an enemy of the church outright, why not instead enthusiastically encourage the growth of the best within it?

\section{An Interfaith Alliance}

Among the most promising developments at the intersection of religion and environmental protection are the fiercely green commitments of the growing international interfaith movement. Interfaith, broadly speaking, is the practice of bringing together leaders and members of diverse religions to learn about each other and to take collective action for the common good. I personally attended the 2015 Parliament 
of World Religions, where care for the earth and combating climate change were a major theme of discussion, and faith leaders from around the world spoke passionately about the necessity for decisive action. Christians hailing from numerous denominations and traditions were represented at the gathering.

This may be a crucial moment in the evolution of Christianity, when the church steps back from its need for hierarchical dominance and embraces a relational path of taking part in a greater whole. Part of the beauty of the Interfaith movement is that by honoring individual traditions so deeply each religion retains its own integrity even as it integrates into a greater whole. Again, the theme of integration rules the day: accepting the "otherness" of different religious traditions goes hand-in-hand with embracing the "other" within, the aspects of divinity that Christianity has split off and repressed. Of course, there will always be fundamentalists in every tradition who reject ontic diversity and epistemic humility, holding out against the evolution of consciousness. It is their right to do so. Pragmatically speaking, the point is not to convince everyone but to build a coalition strong enough to take lasting action in caring for and protecting the Earth.

In How the World's Religions Are Responding to Climate Change (2014), the editors Veldman, Szaz, and Haluza-DeLay open with the following declaration:

A growing chorus of voices has suggested that the world's religions may, individually and collectively, become critical actors as the climate crisis unfolds. Religions affect societies at every level, from the individual to the transnational, as worldviews and as institutions, as conservators of traditions and as resources for change. (p. 3)

Similarly, Reder's (2012) research on religion and climate change reviewed the renewed interest among scholars and social scientists on the relationship between religion and environmentalism, and affirmed the unique powers of religion to create meaning, community, ethical mandates, and motivation for change. As the world's largest religion, Christianity will inevitably play a vital role in this process.

I have noticed over the years that there can be a marked tendency among depth psychologists to dismiss or even demonize Christianity. Often this hostility is born out of wounding experiences from encounters with the darkest shadows of the tradition. I offer no apology or excuse for the wrongs that Christianity as a whole has perpetuated over its long history. I would only point out that if there is shadow, there is also light. Jung believed that Christianity can and must individuate towards a more holistic consciousness, and there is ample evidence to indicate that transformation is now taking place. The church may yet prove an invaluable ally in healing our planet. And given the unprecedented crisis we now face, we cannot afford to make enemies of our allies. 


\section{Works Cited}

Agliardo, M. (2013). The U.S. Catholic response to climate change. In R.G. Veldman, A. Szasz \& R. Haluza-DeLay (Eds.), How the world's religions are responding to climate change (pp. 174192). New York, NY: Routledge.

Berry, T. (1988). The dream of the earth. San Francisco, CA: Sierra Club Books.

Cook, J, Oreskes, N, Doran, D.T., Anderegg, W.R.L., Verheggen, B., Maibach, E.D. ... Rice, K. (2016). Consensus on Consensus: A synthesis of consensus estimates on human-caused global warming. Environmental Research Letters 11 (4). Retrieved from http://iopscience.iop.org/article/10.1088/1748-9326/11/4/048002\#artAbst

Fitzgerald, T. E. (2005). Eastern Christianity. In L. Jones (Ed.), Encyclopedia of religion (2nd ed., vol. 4, 2580-2595). Detroit: Macmillan Reference USA. Retrieved from: http://go.galegroup.com.pgi.idm.oclc.org/ps/i.do?p=GVRL\&sw=w\&u=carp39441\&v=2.1\&it=r \&id=GALE\%7CCX3424500868\&asid=dc9482eabff97f50c0f $89 \mathrm{dca} 29492 \mathrm{f} 10$

Foltz, B.V. (2014). The noetics of nature. New York, NY: Fordham University Press.

Foquet, R. (2013). Handbook on energy and climate change. Northampton, MA: Edward Elger.

Francis. (2015). On care for our common home. Boston, MA: Pauline Books \& Media.

Gerten, D. \& Bergmann, S. (2012). Facing the human faces of climate change. In D. Gerten, \& S. Bergman (Eds). Religion in environmental and climate change (pp. 3-15). New York, NY: Continuum.

Jung, C.G. (1958). A psychological approach to the dogma of the trinity (R.F.C. Hull, Trans). In H.S. Read, M. Fordham, G. Adler (Series Eds.), Psychology and religion: east and west (collected works vol.11, $2^{\text {nd }}$ ed, pp 107-200). New York, NY: Pantheon. (Original published in 1942)

Jung, C.G. (1969). Christ, a symbol of the self (R.F.C. Hull, Trans). In H.S. Read, M. Fordham, G. Adler (Series Eds.), Aion: Researches into the phenomenology of self (collected works vol.9.2, $2^{\text {nd }}$ ed, pp. 36-71). Princeton, NJ: Princeton University Press. (Original published in 1951)

Jung, C.G. (1989). Memories, dreams, reflections (R. Winston \& R. Clara, Trans). A. Jaffe (Ed). New York, NY: Vintage Books. (Original published in 1961)

McKeown, J. (2006, September 19). The use of genesis in debates about environmental stewardship among conservative Christians in the USA. Paper presented at Critical Perspectives on Religion and the Environment, Birmingham, AL.

Northcott, M. (2009). Christianity. In J. B. Callicott \& R. Frodeman (Eds.), Encyclopedia of environmental ethics and philosophy (vol. 1, 147-154). Detroit: Macmillan Reference USA. Retrieved from: http://go.galegroup.com.pgi.idm.oclc.org/ps/i.do?p=GVRL\&sw=w\&u=carp39441\&v=2.1\&it=r \&id=GALE\%7CCX3234100064\&asid=7d4e75d0251436cbf7d164de1 cfbc625

Reder, M. (2012). Religion in the public sphere: the social function of religion in the context of climate and developmental policy. In D. Gerten, \& S. Bergman (Eds). Religion in environmental and climate change (pp. 32-45). New York, NY: Continuum.

Roberts, M. (2012). Evangelicals and climate change. In D. Gerten, \& S. Bergman (Eds). Religion in environmental and climate change (pp. 107-131). New York, NY: Continuum.

Schipperges, H. (1997). Hildegard of Bingen: Healing and the nature of the cosmos (J. Broadwin, Trans). Princeton, NJ: Markus Weiner Publishers. 
Vol. 12, No. 1, 2017

Smith, W.T. (2005). Augustine of Hippo. In L. Jones (Ed.), Encyclopedia of religion (2nd ed., Vol. 2, pp. 624-630). Detroit: Macmillan Reference USA. Retrieved from http://go.galegroup.com.pgi.idm.oclc.org/ps/i.do?p=GVRL\&sw=w\&u=carp39441\&v=2.1\&it=r $\& \mathrm{id}=$ GALE\%7CCX3424500257\&asid=406bd03503c2a39781e41d3cc20a5173

Stein, M. (1985). Jung's treatment of Christianity: The psychotherapy of a religious tradition. Wilmette, IL: Chiron Publications.

Stein, M. (2014). Minding the self: Jungian meditations on contemporary spirituality. London, England and New York, NY: Routledge.

Tarnas, R. (1991). The Passion of the western mind: Understanding the ideas that have shaped our world view. New York, NY: Ballantine Books.

Townsend, P.K. (2014). How many Presbyterians does it take to change a lightbulb? In R.G. Veldman, A. Szasz \& R. Haluza-DeLay (Eds.), How the world's religions are responding to climate change (pp. 192-208). New York, NY: Routledge.

Veldman, R.G., Szasz, A. \& Haluza-DeLay, R. (2014). Social science, religions, and climate change. In R.G. Veldman, A. Szasz \& R. Haluza-DeLay (Eds.) How the world's religions are responding to climate change (pp.3-19). New York, NY: Routledge.

White, L. (1967). The historical roots of the ecological crisis. Science 155, 1203-1207

Zaleha, B.D. \& Szasz, A. (2014). Keep Christianity brown!: climate denial on the Christian right in the United States. In R.G. Veldman, A. Szasz \& R. Haluza-DeLay (Eds.), How the world's religions are responding to climate change (pp.209-228). New York, NY: Routledge. 